\title{
Management of the Valves of the Posterior Urethra in Urology
}

\section{Cyril Kamadjou1, Kimassoum Rimtebaye², Divine Eyongeta ${ }^{3}$, Annie Kameni' ${ }^{1}$, Justin Kamga4, Bertin Njinou1}

\author{
${ }^{1}$ Medico-Surgical Center of Urology and Mini Invasive Surgery, Douala, Cameroon \\ ${ }^{2}$ National General Referal Hospital, N'Djamena, Chad \\ ${ }^{3}$ Regional Hospital, Limbe, Cameroon \\ ${ }^{4}$ General Hospital, Yaounde, Cameroon \\ Email: melinarim@yahoo.fr
}

How to cite this paper: Kamadjou, C., Rimtebaye, K., Eyongeta, D., Kameni, A., Kamga, J. and Njinou, B. (2018) Management of the Valves of the Posterior Urethra in Urology. Open Journal of Urology, 8, 166-170.

https://doi.org/10.4236/oju.2018.85017

Received: February 26, 2018

Accepted: May 12, 2018

Published: May 15, 2018

Copyright (C) 2018 by authors and Scientific Research Publishing Inc. This work is licensed under the Creative Commons Attribution International License (CC BY 4.0).

http://creativecommons.org/licenses/by/4.0/

\begin{abstract}
Aim: Describe the clinical, radiological and management of patients with posterior urethral valves. Materials and Methods: This was a retrospective descriptive study over a period going from January 2011 to December 2016, reviewing 12 cases of patients treated for valves of the urethra posterior to the medical surgical center of urology in Cameroon at Douala. The variables studied were clinical, paraclinical, therapeutic and evolutionary. Results: In 5 years, we had diagnosed and treated 12 cases of posterior urethral valves, an average of 2.4 per year. The average age of patients was 41.6 months with extrems of 3 and 156 months. The reason for consultation was dominated by urinary tract infections. Urethrocystography and echography were performed in all patients and allowed to objectify a bilateral ureterohydronephrosis, a diverticular bladder in 9 cases and 4 cases of vesico-ureteral reflux, including a grade 4 according to the classification of Cendron, 8 patients suffered from acute urinary failure. Renal scintigraphyrealised on 3 patients had as objective in 1 patient the existence of a disfunctioning kidney. The treatment consisted of an endoscopic incision of the valves $(n=8)$, a vesicostomy $(n=3)$ and an iterative urethral dilatation with double $J$ catheter placement $(n=1)$. The evolution was favorable $(n=7)$, and 5 cases of death were recorded. Conclusion: The endoscopic incision is the gold-standard of the treatment of the valves of the posterior urethra. The vesicostomy is an alternative in the absence of adequate technical platform. Despite adequate support, the prognosis remains burdened with significant mortality.
\end{abstract}

\section{Keywords}

Valves of the Urethra, Vesicostomy, Endoscopic Incision, Renal Failure 


\section{Introduction}

The posterior urethra valves (PUV) are the main cause of congenital obstruction in the body [1]. The complications are multiples: urinary infections, reflux Vescico-ureteral, voiding troubles. These complications all explain renal failure in the lack of adequate early care. The valves of the posterior urethra can nowadays be diagnosed in antenatal by a third trimester ultrasound, which diagnosis must be confirmed after the birth. The Uretrocystographie is the reference examination for the diagnosis of certainty of PUV [2]. The treatment has benefit from the evolution of the endoscopy in urology with the miniaturization of the instruments permits an endoscopic incision of the VUP. The prognosis remains bleak despite adequate management.

The purpose of this work was to report our diagnostic approach and to evaluate the management of PUV at the surgical medical Centre of urology.

\section{Materials and Methods}

This was a descriptive retrospective study reviewing 12 records of patients carrying PUV and taken over at the surgical medical Centre of Urology (MSCU) in Cameroon at Douala, from January 2011 to December 2016. Patients were either referred by confreres or consulted spontaneously. Were included patients whom the clinical and paraclinical examinations had allowed to retain the diagnosis of PUV and benefited a management. The variables studied were clinical, paraclinical, therapeutic and evolutionary. Clinical variables were: Age, Consultation reason, weight, temperature, general condition, abdominal distension, flowmetry. Paraclinical variables were done for all patients concerned with: blood count, urea and serum creatinine, ultrasound of the urinary tract, urethrocystography and renal scintigraphy. The therapeutic variables were: endoscopic incision at 12 hours then $5 \mathrm{~h}$ and $7 \mathrm{~h}$, vesicostomy, iterative urethral dilation, and double J catheterization. The evolutionary variables were: regular checking up of patients in external consultation with the completion of an ultrasound of the urinary tree each month for 6 months, aureterocystography, a urine examination and urea and creatinine serum at 3 and Six months. The favorable evolution was pronounced on the basis of the standardization of the Biological constants, the absence of the valves to the urethrocystography of control and the improvement of the clinical signs.

\section{Results}

In 5 years, we had diagnosed and treated 12 cases of posterior urethral valves either an average of 2.4 per year. The average age of patients was 41.6 months with extrems ranging from 3 to 156 months. The reason for consultation was dominated byurinary trac infections. Flow-metry performed in 5 patients had objectified dysuria with a platefull plot. Ultrasound of the urinary shaft had made it possible to suspect the diagnosis in all the patients and also urethrocystography had confirmed this diagnosis by objectifying 4 cases of vesico-uretals reflux in- 
cluding a grade 4 (Figure 1). Bladder diverticula were also objectified in 9 patients by urethrocystography (Figure 2). Scintigraphy performed in 3 patients showed in one case a nonfunctional kidney, 8 patients suffered from acute urinary failure. Cytobacteriological examination of the urine revealed: Escherichia coli $(n=6)$, Klebsiellapneumonia $(n=2)$, Pseudomonas aeruginosa $(n=1)$. The treatment consisted of an endoscopic incision of the valves $(n=8)$ (Figure 3), 3 vesicostomy were done and 2 were closed after 1 year. An iterative urethral dilatation followed by the pose of double "J" probes $(n=1)$. The evolution was favorable $(n=7), 5$ cases of death were related to sepsis $(n=3)$ and end-stage renal failure $(\mathrm{n}=2)$.

\section{Discussion}

The valves of the posterior urethra constitute the most frequent congenital obstructive pathology of the little boy. Its incidence is $1 / 8000$ to $1 / 25,000$ births [3]. Its frequency is unknown in Africa as an evidence to the scarcity of scientific publications.

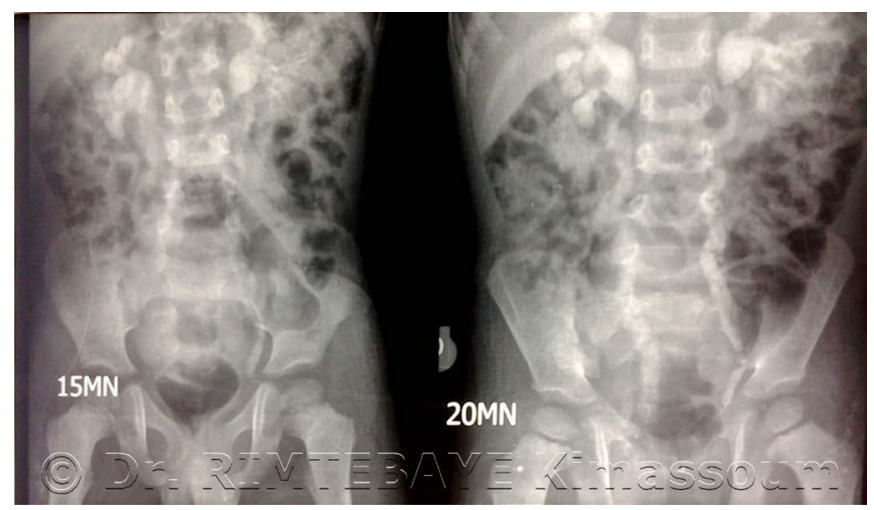

Figure 1. Vesico-uretral reflux including a grade 4.

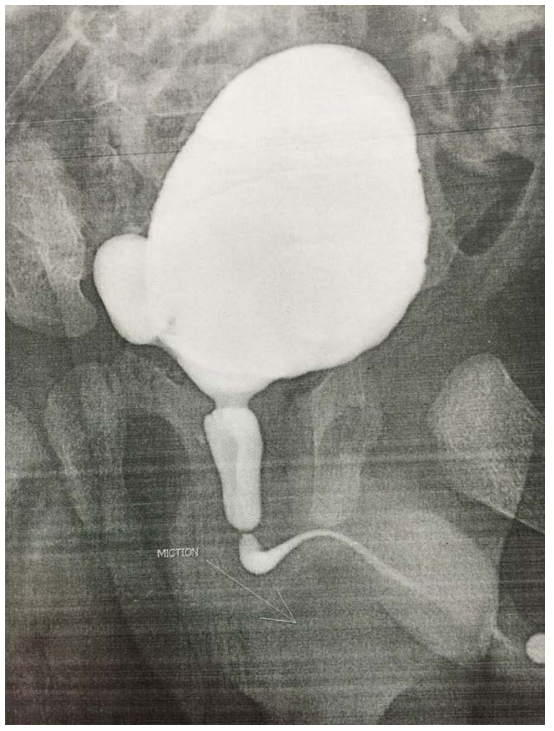

Figure 2. Urethrocystography showing a blader diverticula. 


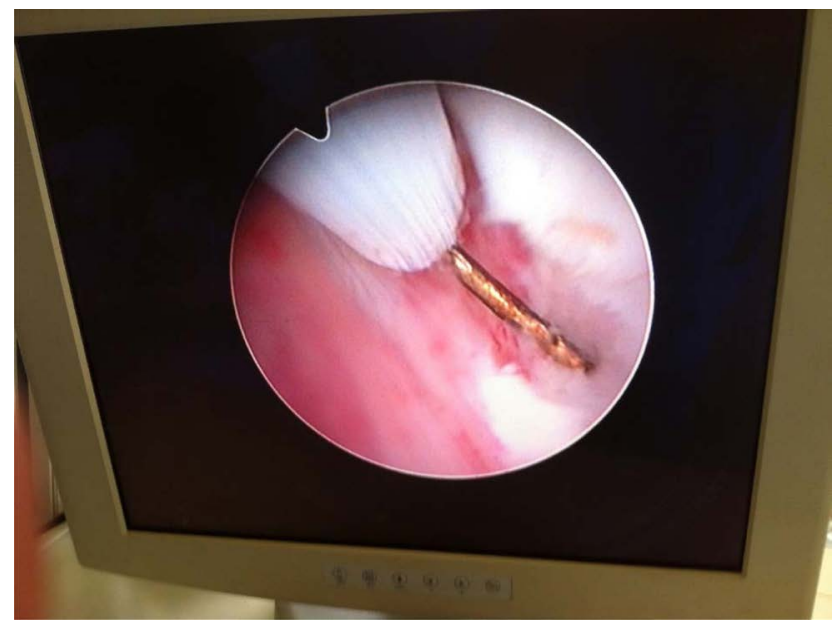

Figure 3. Endoscopic incision of the valve.

The clinical manifestations are diverse and varied: urinary tract infections, voiding disorders, respiratory disorders, digestive disorders, abdominal distension, stunting in the form of harmonious dwarfism. Our study yield a predominance of urinary tract infections as also noted in other studies [4]. The prevalence of Escherichia coli as a germ in the urinary tract infection implies digestive contamination and evidence of poor ano-perino-genital hygiene. The presence of Pyocyanic found in a patient may be related to iatrogenic contamination during multiple urethral manipulations.

Due to its non-invasiveness, antenataleechography has made it possible to suspect of PUV pathologies in 3 cases. Despite adequate management of patients, we recorded 5 cases of death. According to the literature, PUV diagnosed early are poor prognosis in relation to the severity of the cervical obstruction [5].

Urethrocystograhpy retrograde permit us to confirm the diagnosis of PUV, to investigate the complications such as the ureterohydronephrose observed in all patients and the reflux Vescico-ureteral whose presence is a factor of bad prognosis When it is high grade [5].

For a long time, the treatment of PUV used the iterative lamination of the urethra by increasing urinary catheters [6]. Currently, the gold standard of treatment is the endoscopic incision as performed in our study. For very young patients, we opted at first vesicostomy in order to protect the upper urinary tract and postpone the endoscopic incision a few months later. The endoscopic incision of PUV was not performed in 1 patient for persistence of a septic state with pyuria. This patient was subjected to a urethral dilatation with a secondary ascent of JJ-type uretral probes. Some authors recommend drainage of the upper urinary tract in case of inefficiency of bladder drainage [7] [8].

After 6 months of follow-up after treatment, a favorable evolution noted in 7 patients who were subsequently entrusted to a fellow renal-pediatrician. During the follow-up period, we recorded 5 deaths, all in young patients under 3 years of age, which testifies the severity of obstructive character of the PUV. These deaths are related to the obstructive character of PUV, sepsis, and renal function 
degradation.

\section{Conclusion}

Posterior urethra valves are rare congenital obstructive pathology. Clinical manifestations are several and varied. The endoscopic incision remains the gold standard of the treatment. The vesicotomy is an alternative in the absence of adequate technical platform. Despite early and optimal take cares, the prognosis remains fraught with morbidity and significant mortality.

\section{References}

[1] Donohoe, J.M., Weinstein, R.P., Combs, A.J., Misseri, R., Horowitz, M., Schulsinger, D., et al. (2004) When Can Persistent Hydro-Ureteronephrosis in Posterior Urethral Valve Disease Be Considered Residual Stretching. Journal of Urology, 172, 706-711. https://doi.org/10.1097/01.ju.0000129139.10189.3f

[2] Baunin, C., Puget, C. and Gafsi, R. (1997) Troubles Mictionnelsrévélateurs de valves de l'urètrepostérieu: Aspects radiologiques. Archives de Pédiatrie, 4, 14s-18s. https://doi.org/10.1016/S0929-693X(97)86436-6

[3] Perks, A.E., Mac Neily, A.E. and Blair, G.K. (2002) Posterior Urethral Valves. Journal of Pediatric Surgery, 37, 1105-1107. https://doi.org/10.1053/jpsu.2002.33886

[4] Narasimhan, K.L., Chowdhary, S.K., Kaur, B., Mittal, B.R. and Bhattacharya, A. (2006) Factors Affecting Renal Scarring in posterior Urethral Valves. Journal of Pediatric Urology, 2, 569-574. https://doi.org/10.1016/j.jpurol.2005.12.003

[5] Abbo, O., Bouali, O., Ballouhey, Q., Mouttalib, S., Lemandat, A., Decramer, S., et al. (2013) Impact de l'âge au diagnostic sur le devenir à long terme des patients opérés de valves de l'urètre postérieur. Progrès en Urologie, 23, 144-149. https://doi.org/10.1016/j.purol.2012.10.015

[6] Khemakhem, R., Ben Ahmed, Y., Mefteh, S., Jlidi, S., Charieg, A., Louati, H., et al. (2012) Les valves de l'urètre postérieur: A propos de 38 cas. Journal de Pédiatrie, $1-7$

[7] Davody, A.P., Amaro, J.W. and Cukier, J. (1992) Les valves de l'urètre postérieur chez le nouveau-né et le nourrisson: traitement et évolution. Progrès en Urologie, 2, 901-907.

[8] Van Glabeke, E., Philippe-Chomette, P., Montagne, J.P., Audry, G. and Gruner, M. (1997) Intérêt de la néphrostomie percutanée dans la prise en charge des valves de l'urèthre postérieur chez le nouveauné. Progrès en Urologie, 7, 996-1001. 